\title{
STUDY OF THE STABILITY OF COASTAL RECLAMATION SLOPES BY USING GEOTEXTILES AS SOIL STRENGTH
}

\author{
Januario D.C. Fernandes \\ Faculty of Engineering, \\ Narotama University Surabaya \\ januariofernandes6@gmail.com
}

\begin{abstract}
This study presents a simulation of coastal reclamation deposits with geotextiles in areas with the weakest soil profile. Case studies related to deeds and improvement of slopes with woven geotextiles. Observations and investigations show that the land is sand soil which has a low carrying capacity. Weak soil parametric effects, geotextile webbing, external loads, and earthquake loads were analyzed by PLAXIS. The calculation results show reinforcement with woven geotextiles and against external loads and earthquake loads, having a large safety factor.
\end{abstract}

Keywords: Simulation, Geotextile, Reinforcement, Earthquake, External Load.

\section{INTRODUCTION}

The increasing development of construction in Indonesia has led to an increase in the need for land for use in the construction of facilities and public facilities. This encourages people to utilize every available land as best as possible, one of which is in the area, swamps, beaches, rivers, and sloping hills whose topography tends to vary.

Case studies were appointed to find out the slope stability problems that occur in coastal reclamation areas, with the aim of planning the strengthening and repair of geotextile soils and analyzing the handling of geotechnical conditions that occur now and in the future.

From these problems will be answered with the design steps and solutions that are carried out to resolve cases that occur in coastal reclamation. The solution is in the form of analysis carried out with data and information obtained from the field to provide the appropriate report. All preliminary data and information obtained from the field about land cannot provide an overview, so further investigation must be carried out so that an analysis of the problem can be carried out.

Common problems that are often found in slope stability are the small soil stability and low carrying capacity of the soil. The collapse of a slope is often caused by increasing shear stress of a soil mass or decreasing shear strength of a soil mass to be able to withstand forces that are mobilized due to soil mass and the presence of external loads or other factors such as climate, weather and environment. As for how to get the optimal solution to these problems, a reliable analysis of a slope is needed with appropriate repairs and / or soil reinforcement. Various types of soil testing and alternative methods of stabilization with reinforcement related to slope stability are needed analytically and numerically. The problem that often occurs in landfill or reclamation, one of which is the landslide. Then analysis or study of slope stability. Important aspects in slope stability are large loads, rainwater, soil shear strength, soil content weight, slope temperature, soil slope, groundwater pressure, and shock or earthquake.

In the study there are two formulation of the problem:

1. What is the value of the reclamation slope safety factor (SF) with external load or evenly distributed load that is analyzed by the V8.2 plaids program? 
2. What is the value of the security factor (SF) of reclamation slope stability with load of earthquake load analyzed by plaids V8.2 program?

This research was conducted aimed at:

1. Determine the value of the safety factor (SF) of reclamation slope stability with external load or evenly distributed load analyzed by Plaids V8.2 program.

2. Knowing the value of security factor (SF) of reclamation slope stability with load earthquake load analyzed by plaids V8.2 program.

\section{Literature review}

\section{Slope Stability}

The slope of a surface which then forms an angle in a horizontal plane is called a slope. The stability analysis of studies on this sloping surface is called slope stability analysis. This analysis is often used in the design of buildings such as airports, landfills, canals, reclamation, railways, highways, and others. stability analysis, generally carried out to check the safety of the excavation slopes, soil slopes, and natural slopes.

Some of these factors, for example, are anisotropic soil shear strength, water seepage flow in the soil, layers of soil conditions, and others. Terzaghi (1950) divides the causes of slope landslides as a result of external influences and internal influences. External influences are influences that cause increasing shear forces without any changes in soil shear strength. For example, human actions that sharpen the slope of a cliff or deepen a soil excavation and due to river erosion. There are also deep influences, namely landslides that occur without changes in external conditions or earthquakes. For example, a general condition is the condition of the effect of increasing pore water pressure inside a slope.

If a surface forms a slope, the component of the soil mass above the inclined plane tends to move in a lower direction due to gravity. If the gravity or mass component is large enough, it can cause landslides on the slope. This can be prevented by the way the driving force does not exceed the resistance force that comes from the shear strength of the land along the landslide field.

According to (Uswatun, 2012) Slopes are a sloping surface and forms a certain angle to a horizontal plane. In a place where there are two different surface heights, there will be forces that push so that the higher ground position tends to move downward, which is called the gravitational potential force that causes landslides.

\section{Safety factor (SF)}

The safety factor (SF) is defined as the ratio between forces which resist the shear strength of the slope against forces acting on shear stress to meet the balance. Considering the slope is formed by the number of variables and the number of uncertainty factors including soil parameters such as soil shear strength, pore water pressure conditions, then simplification is carried out in analyzing various assumptions. Theoretically the moving mass can be stopped by increasing its shear strength.

$\mathrm{Fk}=\frac{c+\sigma \tan \varphi}{c d+\sigma \tan \varphi d} \ldots \ldots \ldots \ldots \ldots \ldots \ldots . . . . . . . . . .1$

Now we can find out some of the other parameters that affect the security number, namely the number of safety against cohesion, Fc, and the safety number of the $\mathrm{F}$ geser shear angle. Thus we can define $F c$ and $F \varphi$ as: 
$\mathrm{F}_{\mathrm{c}}=\frac{C}{C d} \quad \operatorname{dan} F_{\varphi}=\frac{\tan \varphi}{\tan \varphi d} \ldots \ldots \ldots \ldots \ldots . . . . . .$.

When the equation of comparison is natural, if $F c$ becomes equal to $F \varphi$, the price gives a safeity number to the strength of the land. Or, if

$$
\frac{c}{c d}=\frac{\tan \varphi}{\tan \varphi d} \ldots \ldots \ldots \ldots \ldots \ldots . . . \cdots
$$

\section{Goetextile}

In the study (Saputra, 2017) Geotextile is one type of geosynthetic or artificial product made from polymer materials that serves to strengthen or improve soil performance. In the process of making geotextiles, textile elements such as fibers or several strands of fiber are combined into a sheet textile structure. The type of geotextile is then divided based on the method used to combine filaments or ribbons into sheet structures. The main types of geotextiles are woven and woven, and knitted.

\section{RESEARCH METHODOLOGY}

The location to be analyzed is Reclamation located in the bay of the city of Ambon, Maluku.

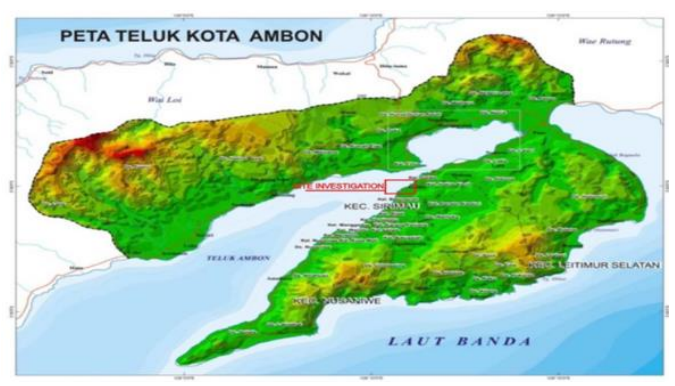

Fig 1. Location

The data used in this study is secondary data which is data taken from the (Darjanto, Laporan Akhir Proyek Dan Draf Manual Kestbilan Lereng, 2014) Meanwhile the soil parameters used in the analysis of reclamation slope stability are soil data at $\mathrm{BH}-07$ point.

Table 1. BH-07 soil parameter data

\begin{tabular}{|l|c|c|c|}
\hline & $\begin{array}{c}\text { Gravelly } \\
\text { sand }\end{array}$ & Silty sand & $\begin{array}{c}\text { Medium } \\
\text { Sand }\end{array}$ \\
\hline kedalaman & $0-9$ meter & $9-14$ meter & $>14$ meter \\
\hline Type & Drained & Drained & Drained \\
\hline $\boldsymbol{Y}_{\text {dry }} \mathbf{k N} / \mathbf{m}^{3}$ & 12 & 12.7 & 14 \\
\hline $\boldsymbol{\gamma}_{\text {sat }} \mathbf{k N} / \mathbf{m}^{3}$ & 19 & 17.6 & 20 \\
\hline $\mathbf{E}_{\text {ref }} \mathbf{k N} / \mathbf{m}^{\mathbf{2}}$ & 7000 & 15000 & 22000 \\
\hline $\mathbf{V}$ & 0.3 & 0.3 & 0.3 \\
\hline $\mathbf{C}_{\text {ref }} \mathbf{k N} / \mathbf{m}$ & 5 & 5 & 1 \\
\hline $\boldsymbol{\varphi}$ & 30 & 32 & 36 \\
\hline $\boldsymbol{\Psi}$ & 0 & 2 & 6 \\
\hline
\end{tabular}


Table 2. Embankment soil parameter data

\begin{tabular}{|l|c|c|}
\hline & Fill soil & Quarry Stone \\
\hline Type & Drained & Drained \\
\hline $\boldsymbol{\gamma}_{\text {dry }} \mathbf{k N} / \mathbf{m}^{\mathbf{3}}$ & 16 & 22 \\
\hline $\boldsymbol{\gamma}_{\text {sat }} \mathbf{~ k N / \mathbf { m } ^ { 3 }}$ & 20 & 22 \\
\hline $\mathbf{E}_{\text {ref }} \mathbf{k N} / \mathbf{m}^{\mathbf{2}}$ & 8000 & 69000 \\
\hline $\mathbf{V}$ & 0.3 & 0.2 \\
\hline $\mathbf{C}_{\text {ref }} \mathbf{k N} / \mathbf{m}^{\mathbf{2}}$ & 5 & 5 \\
\hline $\mathbf{\varphi}$ & 30 & 45 \\
\hline $\boldsymbol{\Psi}$ & 0 & 10 \\
\hline
\end{tabular}

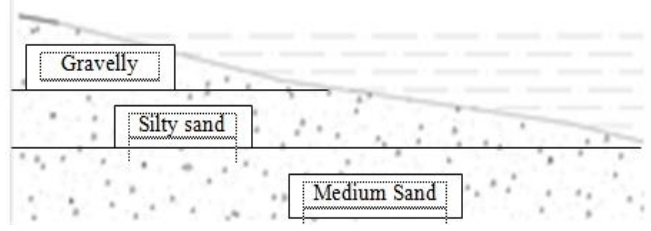

Fig 2. Cross Section Soil Existing

The geometries of alternative modeling are as follows:

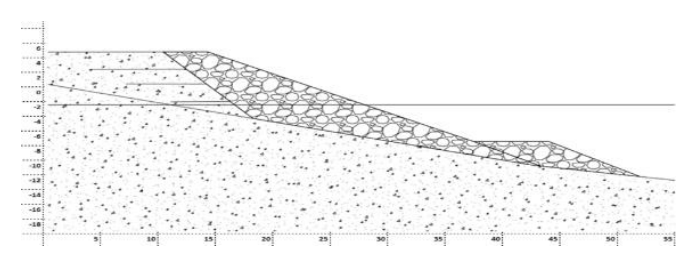

Fig 3. Model Design 1

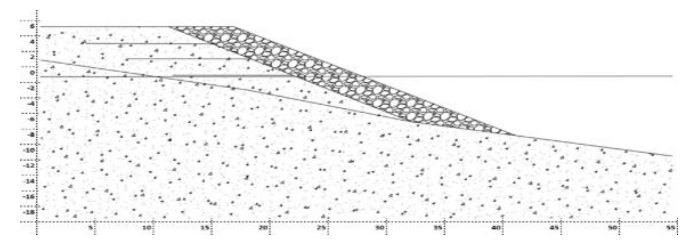

Fig 4. Model Design 2

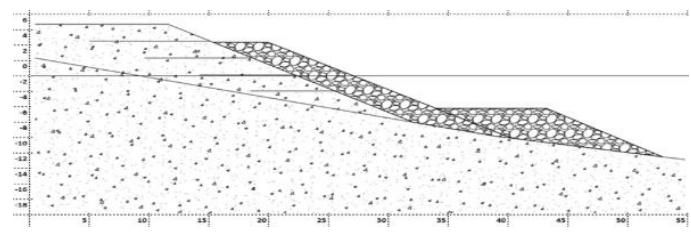

Fig 5. Model Design 3

\section{RESULTS AND DISCUSSION}

Analisys With Programe Plaxix V8.2

Vertical Loading 
Slope conditions due to Vertical load / external load of $10 \mathrm{kN} / \mathrm{m} 2$ which shows displacement in all three models of reclamation slope stability can be seen in table 5, below:

Table 3. Displacement due to vertical load.

\begin{tabular}{|c|c|c|c|}
\hline \multirow{2}{*}{ No } & \multicolumn{3}{|c|}{ vertical load } \\
\cline { 2 - 4 } & & displacement & unit \\
\hline 1 & model 1 & 15.183 & $\mathrm{~cm}$ \\
\hline 2 & model 2 & 15.155 & $\mathrm{~cm}$ \\
\hline 3 & model 3 & 14.460 & $\mathrm{~cm}$ \\
\hline
\end{tabular}
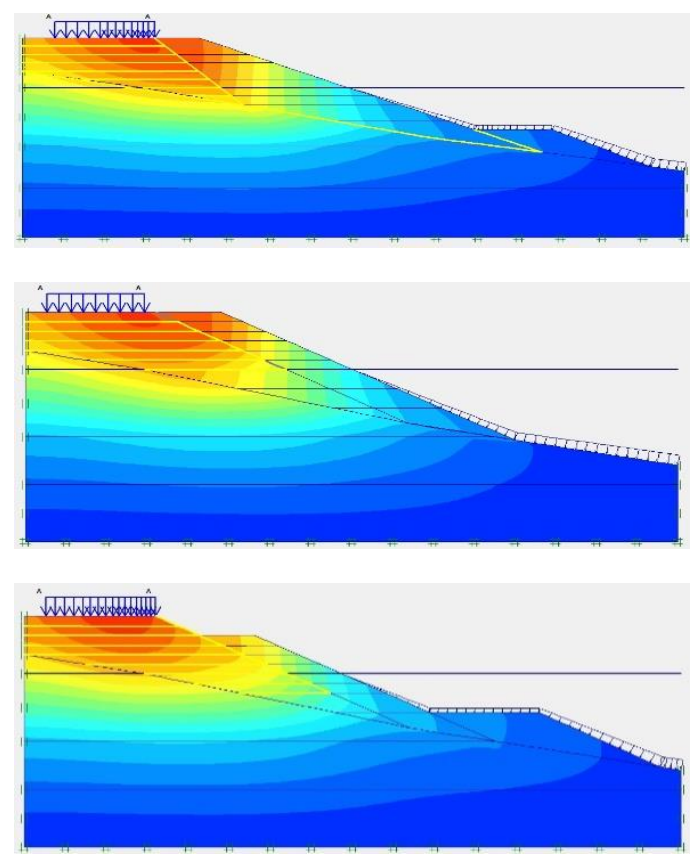

Fig. 6. Vertical Loading

Horizontal Load

Slope conditions due to horizontal load /earthquake load $0.25 \mathrm{~g}$ which shows displacement in all three models of reclamation slope stability can be seen in table 5 , below:

Table 4. Displacement due to earthquake load.

\begin{tabular}{|c|c|c|c|}
\hline \multirow{2}{*}{ No } & \multicolumn{3}{|c|}{ earthquake load / horizontal } \\
\cline { 2 - 4 } & & displacement & unit \\
\hline 1 & model 1 & 28.917 & $\mathrm{~cm}$ \\
\hline 2 & model 2 & 30.699 & $\mathrm{~cm}$ \\
\hline 3 & model 3 & 29.847 & $\mathrm{~cm}$ \\
\hline
\end{tabular}



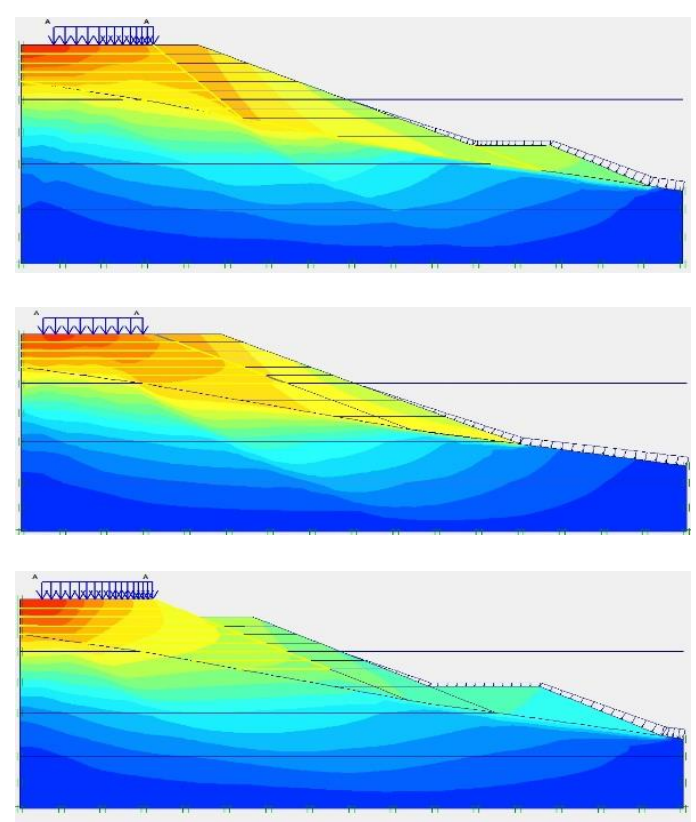

Fig. 7. Horizontal Load

Safety Factor (SF)

Vertical load safety factor

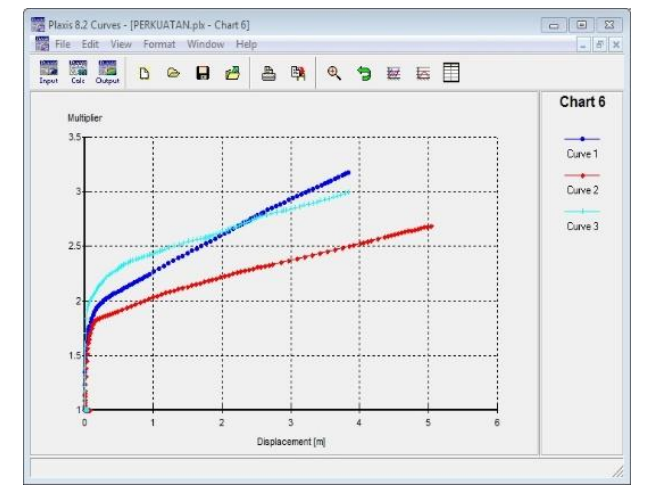

Fig.8. Graph vertical load safety factor

Safety factor horizontal load/ earthquake load.

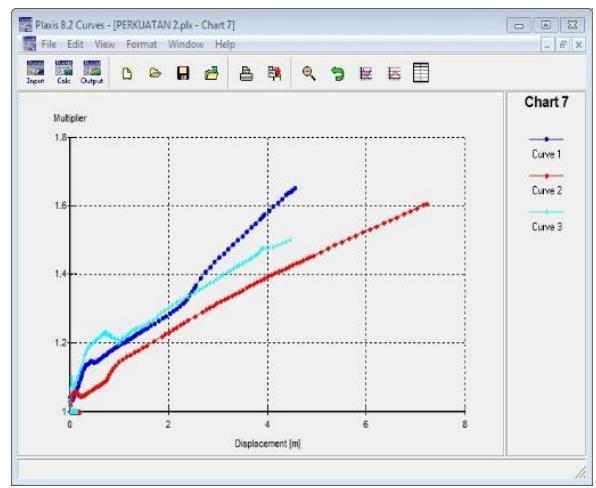

Fig.9.Graph vertical load safety factor 
Table.6. Recapitulation of safety factors

\begin{tabular}{|c|c|l|c|}
\hline No & Model & \multicolumn{1}{|c|}{ Beban } & Stabilitas Kelongsoran(SF) \\
\hline \multirow{2}{*}{1} & \multirow{2}{*}{ Permodelan 1 } & beban Luar & 3.172 \\
\cline { 3 - 4 } & & beban Gempa & 1.651 \\
\hline \multirow{2}{*}{2} & \multirow{2}{*}{ Permodelan 1 } & beban Luar & 2.685 \\
\cline { 3 - 4 } & & beban Gempa & 1.606 \\
\hline \multirow{2}{*}{3} & \multirow{2}{*}{ Permodelan 3 } & beban Luar & 2.989 \\
\cline { 3 - 4 } & & beban Gempa & 1.499 \\
\hline
\end{tabular}

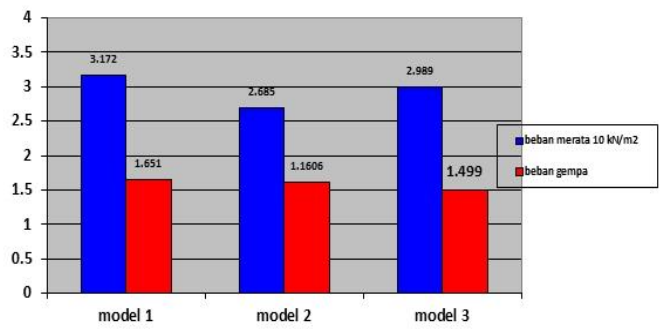

Fig. 10. Safety factor graph from 3 numerical modeling.

\section{CONCLUTION}

Based on research that has been described from the results and discussion, then some conclusions can be drawn as follows:

1. On reclamation slope stability with geotextile as soil reinforcement in all three models with evenly distributed loads analyzed by plaids program V8.2 got SF in model 1, modeling 2 and modeling $3=3.172,2.685$, and 989 then the slope was said to be stable.

2. The results of the analysis of reclamation slope stability due to earthquake load with the Palxis V8.2 program on the three slope models that obtained SF in model 1, modeling 2 , and modeling $3=1,651,1,601$, and 1,499, then the slope was said to be stable.

Suggestion

1. Further land strengthening needs to be done because the geotextile reinforcement of land cannot overcome the landslide field.

2. If it is necessary to do additional reinforcement such as reinforcement with achor or with a plate on the front of the pile after reinforcement with geotextile in order to overcome the large landslide field.

3. Perform analysis with different methods such as the bishop method, filenius method, or with other computers to get the results of the analysis.

4. Perform different slope modeling and and reinforcement and different methods to compare the results of calculations. 


\section{REFERENCE}

[1]. Bagus Ratna saputra, S. (2017). An Analisys Of Stability Slope By The Use Of Bamboo As An Alternative Bracing (A Case Study : Road Area Grogol Semarang City). Proceding of International Conference.

[2]. Bowles, J. E. (1986). Sifat-sifat Fisis Dan Geoteknis Tanah (Mekanika Tanah). jakarta: Penerbit Erlangga.

[3]. Brinkgreve, R. (2005). PLAXIS 2D-Versi 8. Belanda: PLAXIS b.v.

[4]. Darjanto, H. (2014). Laporan Akhir Proyek Dan Draf Manual Kestbilan Lereng.

[5]. Das, B. M. (2007). Principles Of Foundation Enginering-6th Edition. Toronto, Ontario, Canada: Nelson, A Division Of Thomson Canada Limited.

[6]. De-Jian Li, L.-H. X. (n.d.). Stability Analysis of Seismic Sloipe with Cracks. Research Paper.

[7]. Hardiyatmo, H. C. (2003). Mekanika Tanah II Edisi Ketiga. Yogyakarta: Gajah Mada University Press.

[8]. Hardyatmo, H. C. (2007). Meknika Tanah 2 . Yogyakarta: Gajah Mada University Press.

[9]. Lavinia Muntean, M. G. (2016). Slope Stability Railway Embankments. Proceding Engineering .

[10].Naima Benmebarek, S. F. (2014). Effect of Geosynthetic reinforced embankment on locally weak zones by numercial approach. research paper.

[11].Pradhana, R. (2015). Analisis Stabilitas Lereng Dengan Perkuatan Geotekstil. Tugas Akhir. Universitas Islam Indonesia.

[12].Saputra, S. A. (2017). Analisis Stabilitas Lereng Dengan Perkuatan Dinding Penahan Tanah Tanah Kantivaler Dan Geotekstil Pada Ruas Jalan Lintas LiwaSimpang Gunung Kemala KM. 268+550. Tugas Akhir.

[13].SNI:8460. (2017). Persyaratan Perancangan Geoteknik. Jakarta: Badan Standarisasi Indonesia.

[14].Souici Messoud, H. B. (2017). Investigastion of Building Loads Effect on the Stability of Slope. World Academy of Science, Engineering and Technology International Journal of Civil and Environmental Engineering.

[15].Sousa, M. C. (2017). Slope Stability in Road Infrastruktures. research paper.

[16].Uswatun, C. (2012). Analisis Stabilitas Lereng Dengan Perkuatan Geotekstil Menggunaka Program Geoslope. Surakarta: Universitas Sebelas Maret.

[17].Waleed Abdel karim, A. (2017). Stability of Slope on Clays Variable Strength by Limit Equilibrium and Fenite Element Analysis. international Journal Of Geomate. 